\title{
The Wealthy World's Open-Economy from FDI Inflow Is a Real Thing: Malaysia's Experience
}

\author{
Shairil Izwan Taasim ${ }^{1, *}$, Sharon Yong Yee Ong ${ }^{1}$, Neilson Anak Teruki ${ }^{1}$, Anita Rosli ${ }^{1,2}$, Adrian Daud ${ }^{1,2}$, \\ Edwin Anak Francis ${ }^{3}$ \\ ${ }^{1}$ Department of Social Science and Management, Faculty of Humanities, Management and Science, Universiti Putra Malaysia Bintulu, \\ Sarawak Campus, Malaysia \\ ${ }^{2}$ Institut EkoSains Borneo, Universiti Putra Malaysia Bintulu Sarawak Campus, Malaysia \\ ${ }^{3}$ Cluster of Business and Management, Open University Malaysia, Malaysia
}

Received July 22, 2021; Revised September 10, 2021; Accepted October 17, 2021

\section{Cite This Paper in the following Citation Styles}

(a): [1] Shairil Izwan Taasim, Sharon Yong Yee Ong, Neilson Anak Teruki, Anita Rosli, Adrian Daud, Edwin Anak Francis , "The Wealthy World's Open-Economy from FDI Inflow Is a Real Thing: Malaysia's Experience," Universal Journal of Accounting and Finance, Vol. 9, No. 5, pp. 1191 - 1198, 2021. DOI: 10.13189/ujaf.2021.090528.

(b): Shairil Izwan Taasim, Sharon Yong Yee Ong, Neilson Anak Teruki, Anita Rosli, Adrian Daud, Edwin Anak Francis (2021). The Wealthy World's Open-Economy from FDI Inflow Is a Real Thing: Malaysia's Experience. Universal Journal of Accounting and Finance, 9(5), 1191 - 1198. DOI: 10.13189/ujaf.2021.090528

Copyright $\bigcirc 2021$ by authors, all rights reserved. Authors agree that this article remains permanently open access under the terms of the Creative Commons Attribution License 4.0 International License

\begin{abstract}
Fiscal policy is one of the popular instruments used by government to provide balance to growth in the national economy and market. In Malaysia's context, fiscal policy is implemented using such as the annual budgets, Malaysia Plans, and multiple stimulus packages aimed at boosting Malaysia's economy especially during the recent lock down which has threatened to cause an economic crisis due to the Covid-19 pandemic. Additionally, one of the Malaysian Government's biggest spending using fiscal policy is its development expenditure, and tax is one of the largest contributions used to support this development expenditure. In order to attract investors to Malaysia, critical features such as benefits, facilities, and social welfare have been designed by decision-makers in each formulated policy. Initiatives such as inter-governmental forums, trade agreements and discussions are platforms that can be used to share and respond to economic problems. However, the existence of competition and foreign policy have become major challenges to the country's efforts to attract investors. Therefore, the aim of this study is to investigate the relationship between Malaysia's federal government development expenditure with foreign direct investment (FDI) inflow, as well as the country's openness towards investment. The two dimensions of asymmetric FDI inflow were analysed to see how they react to government expenditure from 1970 until 2019 using the Linear and
\end{abstract}

Nonlinear Autoregressive Distributed Lag method. Findings from the Nonlinear Autoregressive Distributed Lag Model (NARDL) model indicated that FDI has a positively significant effect on fiscal accumulation for development expenditure. In conclusion, increases in government expenditure increase FDI inflow into Malaysia in both the short- and long-run. Hence, government development expenditure behaviour represents accelerating economic growth in the Malaysian context, and it is proven to have a significant impact towards economic growth in the long-run. This study contributes to empirical literature on the relationship between federal government development expenditure and FDI inflow, particularly the effect of openness to investment into a developing country towards economic growth in the longrun.

Keywords Asymmetric, Competition, Investment, Economic Growth

\section{Introduction}

The "invisible hand" concept in the open market system is a metaphor introduced by economist Adam Smith to represent the role of the government. In this perspective, 
the government plays the role as an arbitrator to provide balance to growth in both the national economy and the market. A popular instrument used by the government is fiscal policy. Malaysia has its annual budgets, Malaysia Plans, and stimulus packages as part of its fiscal policy used to boost the economy. When Malaysia went into lockdown due to the Covid-19 pandemic, the situation had posed the threat of an economic crisis. To combat this, the government introduced more than five stimulus packages: PRIHATIN, PENJANA, PERMAI, PEMERKASA, PEMERKASA PLUS, and PEMULIH as fiscal instruments implemented to recover the economy. RM530 billion were allocated for these packages. A government's spending on fiscal policy is divided into two categories: operating and development expenditures. Barro [3] stated that the impact of government spending may vary depending on the component of government expenditure that is under consideration. In the Shared Prosperity Vision 2030 which aims to establish and enlarge the business ecosystem and industry in Malaysia, fiscal sustainability is pursued through sustained government financing and strengthened investor confidence.

Taxes is one of the largest contributions to the government used to support development expenditure. The percentage of taxes imposed on personal income is different for individual residents or non-residents working in Malaysia and the corporate sector. However, in order to attract investors to Malaysia, critical features such as benefits, facilities, and social welfare have been placed in each policy by decision-makers. Lim, Shivee, and Woon [16] stated that among these features are attractive tax incentives, liberal equity policies, and the employment of expatriates. These features are included due to the competitive market nowadays. To increase the real income of the country and compete with other regions, development expenditure is crucial to boost growth. According to Chen, Lv, and Liu [6], the slow development of the financial sector has long been identified as one of the most binding constraints on economic growth, especially in developing countries.

Malaysia has implemented zero-based budgeting for its expenditures since 2019 in order to strengthen the federal government finances. This concept is developed based on the needs and abilities to implement without affecting government services to the society. Initiatives viewed as having a trickle-down effect from the government towards the society are mega projects such as the Klang Valley Mass Rapid Transit (MRT), Tun Razak Exchange, and the Pan Borneo Highway which are seen as national plans to accelerate economic growth and attract foreign investors. The government plans and implements mega projects in its annual budgets or Malaysia Plans. Katiman et al.[15] reported that socioeconomic impacts, increasing per-capita income, household occupation, and quality of life are some of the benefits that Iskandar Malaysia has provided as one of the country's mega projects.
In Malaysia, the annual allocation by sector is different due to financial constraints and other political issues. According to Dreher, Sturm, and Ursprung [7], the government tends to reduce expenditures on transfers and subsidies because of globalisation. However, the Malaysian government has also improved and stabilized its annual budgets with other kinds of incentives. According to Chen et al. [6], there is less attention to the determinants of government expenditure composition. To fill this gap, our research focused on the short-run and long-run relationship between government spending and mobility policy in attracting investors to Malaysia. Charles [5] stated that the barrier to most incentive-based competitions is effectively intra-regional since much of real investment that national and sub-national governments compete for is investment that investors intend to locate in a particular region. The existence of competition and foreign policy has become a major challenge to the country in attracting investors. This paper contributes to the debate on development expenditure by addressing federal debt due to development made specifically to attract foreign investment. The authors studied whether there is a relationship between federal development expenditure in Malaysia with foreign direct investment inflow, as well as openness towards investment. The rest of the paper is organized as follows: Section 2 presents the relevant literature, Section 3 discusses the estimation and model of study, and the last section presents the overall discussion and policy implications.

\section{Literature Review}

Government expenditure's main contribution to a country's economic growth has been discussed and debated in various fields of literature. Government expenditure is a tool that can attract investment and develop certain places or sectors. Since 1970, the value of government expenditure has increased as shown in the annual budgets. The main aspect of a government expenditure is more towards generating and increasing a country's income in order to sustain economic growth. This is the reason why Malaysia has introduced its annual budgets and the long-term Malaysia Plans as tools to plan and determine the country's vision and mission. An earlier study by Solow (1956) showed how government spending has an impact towards economic growth, where in the long-run growth is exogenously driven by technical progress and assumes transitory effects of shocks to fiscal policy on economic growth. Barro [3] mentioned that the impact of government spending may vary depending on the component of government expenditure that is under consideration. Easterly and Rebelo [8] in their time series study found that public investment is consistently correlated to economic growth. Barro [3], on the other 
hand, confirmed the detrimental effect of the public sector on economic growth.

Malaysia's government expenditure has increased from only RM72.5 million in 1970 to RM45,962 million in 2016. Although the amount of the budget always fluctuates, the trendline is found to increase every year. In fact, ever since the implementation of the New Economic Model in 1970, Malaysia's expenditure has been greater than $300 \%$. Generally, infrastructure, education, social, and defense are the main aspects in a government's expenditure as these factors are more likely to attract high FDI and income. However, the volume of development expenditure for Malaysia by share of GDP is only around $3.5 \%$ to $4.4 \%$ for the years of $2019-2021$. The debate about government development expenditure has gained fresh prominence, with arguments by Gunby et al. [11] who posited that the growth in Chinese FDI was guided by public policy, with the reason being that the key elements in a policy affect the economy at the firm level.

The importance of saving and investing in supporting growth has been emphasised on by the Harrod-Domar model. The government's investment helps boost economic growth and attract FDI. A number of authors have reported a contradicting relationship between FDIs and other sectors in the economy. Waqih et al. [23] stated that FDIs and $\mathrm{CO}_{2}$ emissions in an empirical time series study portrayed an inverted-U relationship. Meanwhile, Munir and Ameer [18] reported that Pakistan's economic growth and increase in FDI have increased $\mathrm{CO}_{2}$ emissions. Gunby et al. [11] discovered evidence of FDI-related productivity spill-overs in China, and these spill-overs have been of sufficient size to affect growth at the aggregate level.

Government debt is always debated on as the volume of debt affects economic growth in the long run. The crowding-out effect of government expenditure on debt has several potential elements. Feyzioglu, Swaroop, and Zhu [9] showed that when governments receive foreign funding for education, they tend to cut back on their own spending in the sector. A study in China by Tang et al. [22] showed the importance of government spending in increasing intergenerational and improving equality. Meanwhile, evidence on government policy in expenditure have raised concerns about its distortionary effect on the market and other indicators of economic growth, especially in achieving the Shared Prosperity Vision 2030.

\section{Methodology}

In this section, the authors developed an econometric analysis on the nexus between economic growth, government development expenditure as well as foreign direct investment (FDI). All variables have been converted into a natural log form. The data were collected for various years from the Economic Planning Unit and the Ministry of Finance. We employed an empirical model based on the endogenous growth model of Barro, [3] which assumes the role of government public expenditure in order to generate outcomes that affect political stability, human capital, and market distortions.

Table 1. Malaysia's Development Expenditure

\begin{tabular}{|c|c|c|c|c|c|c|c|c|c|}
\hline \multirow{2}{*}{ Sector } & \multicolumn{3}{|c|}{ RM Million } & \multicolumn{3}{c|}{ Change (\%) } & \multicolumn{3}{c|}{ Share (\%) } \\
\cline { 2 - 12 } & $\mathbf{2 0 1 9}$ & $\mathbf{2 0 2 0}$ & $\mathbf{2 0 2 1}$ & $\mathbf{2 0 1 9}$ & $\mathbf{2 0 2 0}$ & $\mathbf{2 0 2 1}$ & $\mathbf{2 0 1 9}$ & $\mathbf{2 0 2 0}$ & $\mathbf{2 0 2 1}$ \\
\hline Economic & 31,300 & 28,525 & 38,887 & -13.3 & -8.9 & 36.3 & 57.8 & 57.1 & 56.4 \\
\hline Social & 14,484 & 13,058 & 18,369 & $12.5-$ & -9.8 & 40.7 & 26.7 & 26.1 & 26.7 \\
\hline Security & 5,614 & 5,557 & 7,780 & 13.9 & -1.0 & 40.0 & 10.4 & 11.1 & 11.2 \\
\hline General Administration & 2,775 & 2,860 & 3,964 & 26.7 & 3.1 & 38.6 & 5.1 & 5.7 & 5.7 \\
\hline Share of GDP (\%) & 3.6 & 3.5 & 4.4 & & & & & & \\
\hline
\end{tabular}

Source: [19]

Table 2. Summary of Selected Variables

\begin{tabular}{|c|c|c|c|}
\hline Variables & Short Form & Measurements & Sources \\
\hline Government development expenditure & EXP & RM Billion & Ministry of Finance Malaysia \\
\hline Economic Growth & GDP & GDP Per capita (Current USD) & $\begin{array}{c}\text { World } \\
\text { Development Indicator } \\
\text { (WDI) }\end{array}$ \\
\hline Foreign Direct Investment in Flow & FDI & $\begin{array}{c}\text { Percentage of GDP (Current } \\
\text { USD) }\end{array}$ & $\begin{array}{c}\text { Development Indicator } \\
\text { (WDI) }\end{array}$ \\
\hline Trade Openness & TROP & $\begin{array}{c}\text { Ratio of total trade (exports plus } \\
\text { imports) in GDP, }\end{array}$ & $\begin{array}{c}\text { World } \\
\text { Development Indicator } \\
\text { (WDI) }\end{array}$ \\
\hline
\end{tabular}

Source: Authors' compilation 
In our basic model for analysis, government development expenditure $\left(\mathrm{G}_{\mathrm{EXPt}}\right)$, Gross Domestic Product (GDP) per-capita $\left(\mathrm{GDP}_{\mathrm{PCt}}\right)$, foreign direct investment inflow $\left(\mathrm{FDI}_{\mathrm{IFt}}\right)$, and trade openness $\left(\mathrm{TRO}_{\mathrm{POPt}}\right)$ are the proxies by import and export to be divided by total GDP. Intercept is represented by $\mathrm{C}$ and residual by $\mathrm{U}_{\mathrm{t}}$. Hence, the simple OLS-three variable model takes the following form:

$$
\mathrm{G}_{\mathrm{EXPt}}=\mathrm{C}+\beta 1 \mathrm{GDP}_{\mathrm{PCt}}+\beta 2 \mathrm{FDI}_{\mathrm{IFt}}+\beta 2 \mathrm{TRO}_{\mathrm{POPt}}+\mathrm{U}_{\mathrm{t}}
$$

Next is the three-step econometric procedure, ARDL. First, a time series unit root test was applied for the stationary test. The stationary test was done on each variable to avoid spurious regression problems since the OLS minimizes the summed squared residuals and the regression estimation is sensitive to residuals from large data. Taasim and Yusoff [21] stated that time series data is stationary if its mean and variance are constant over time. Granger and Yoon [12] reported that in order to test the existence of a long-run relationship, an EC model should be estimated with the lagged residual. A bounds testing procedure can be used to draw conclusive inference without knowing whether the variables are integrated of order zero or one, $\mathrm{I}(0)$ or $\mathrm{I}(1)$, respectively as put by Pesaran, Shin, and Smith [14] and Pesaran and Shin [13].

$$
\begin{gathered}
\Delta y_{t}=c_{0}+\gamma \hat{v}_{t-1}+\sum_{i=1}^{p-1} \varphi_{y i} \Delta y_{t-i}+\sum_{i=0}^{q-1} \varphi_{x i}^{\prime} \Delta x_{t-i}+\mu_{t} \\
-1 \leq \gamma<0
\end{gathered}
$$

The long-run relationship is expressed as Equation 4, where $\mathrm{y}_{\mathrm{t}}$ represents the development expenditure of the government. Ak, Kirca, and Altintaş [1] stated that $\mu_{\mathrm{t}}$ is a vector of deterministic regressors (trends, season, and other exogenous variables). When the development expenditure and FDI are nonlinear (asymmetric), Shin et al. [20] proposed the NARDL model as positive and negative partial sums. Asymmetric cointegration is implied if the time series is noted to have cointegration using their positive and negative components, as posited by Granger and Yoon [12]. Shin et al. [20] proposed the nonlinear ARDL cointegration approach (NARDL) as an asymmetric extension to the well-known ARDL model of Pesaran and Shin [13] and Pesaran et al. [14].

$$
\Delta y_{t}=c_{0}+\beta_{1} F D I_{t}^{+}+\beta_{2} F D I_{t}^{-}+\beta_{3} G D P c_{t}+\beta_{4} T D_{t}+\varepsilon_{t}
$$

The values of $F D I_{t}^{+}$and $F D I_{t}^{-}$are the partial sums of the positive and negative in the foreign direct investment inflow.

$$
\begin{array}{r}
F D I_{t}^{+}=\sum_{i=1}^{t} \Delta F D I_{t}^{+}=\sum_{i=1}^{t} \max \left(\Delta F D I_{i}, 0\right) \\
\text { and } F D I_{t}^{-}=\sum_{i=1}^{t} \Delta F D I_{t}^{-}=\sum_{i=1}^{t} \max \left(\Delta F D I_{i}, 0\right)
\end{array}
$$

After the model obtained the optimum lags, a cointegration bound testing was applied as in Pesaran et al. [14] to identify the presence of cointegration variables. To identify the presence of asymmetry, analysis using the Wald test was employed for the long-run. The existence of a long-run/cointegrating relationship can be tested based on the EC representation (Ahad and Dar, [2]). These techniques are only applicable when the data series are integrated at the same level, i.e., I(0) or I(1).

\section{Empirical Results}

The authors' focus in this section is to identify the stationarity of the time series and the data integration at I(1) for all variables involved. Annual data from 1970 to 2017 were employed in the analysis. Table 3 represents the descriptive statistics of the 46 observations. Based on the statistics, FDI (dfdi) has the highest ranking for mean and standard deviation at 9.390 and 0.546 , respectively. The trade openness (dtrop) variable has the lowest values for mean and standard deviation.

Table 3. Summary of Descriptive Statistics

\begin{tabular}{|c|c|c|c|c|c|}
\hline Variable & Obs & Mean & $\begin{array}{c}\text { Std. } \\
\text { Dev. }\end{array}$ & Min & Max \\
\hline dexpg & 46 & 4.194 & 0.427 & 3.274 & 4.734 \\
\hline dgdp & 46 & 3.565 & 0.344 & 2.883 & 4.058 \\
\hline dtrop & 46 & 0.156 & 0.119 & -0.043 & 0.343 \\
\hline dfdi & 46 & 9.390 & 0.546 & 8.059 & 10.179 \\
\hline
\end{tabular}

Before ARDL and NARDL were employed in the analysis, the Augmented Dickey Fulley (ADF) and Philips-Perron (PP) analyses were first conducted to examine the time series properties of the variables and to compute the unit root statistics. A nonstationary series has one or more basic properties that do change over time. The results are shown in Table 4. Since the test results show that a number of variables are significant I(1), the analysis then proceeded to the bound testing procedure. The null hypothesis is accepted if the value of the $\mathrm{t}$-statistic is more than the t-critical. 
Table 4. Unit Root Test (Constant and Trend)

\begin{tabular}{|c|c|c|c|c|c|c|c|c|}
\hline \multirow{2}{*}{ Variables } & \multicolumn{4}{|c|}{ Level } & \multicolumn{4}{c|}{$1^{\text {st }}$ Difference } \\
\cline { 2 - 9 } & \multicolumn{2}{|c|}{ ADF } & \multicolumn{2}{c|}{ PP } & \multicolumn{2}{c|}{ ADF } & \multicolumn{2}{c|}{ PP } \\
\cline { 2 - 9 } & Constant & $\begin{array}{c}\text { Constant } \\
\text { and Trend }\end{array}$ & Constant & $\begin{array}{c}\text { Constant } \\
\text { and Trend }\end{array}$ & Constant & $\begin{array}{c}\text { Constant } \\
\text { and Trend }\end{array}$ & Constant & $\begin{array}{c}\text { Constant } \\
\text { and Trend }\end{array}$ \\
\hline dexpg & -1.738 & -3.054 & -1.874 & -2.165 & $-4.631^{*}$ & $-4.676^{*}$ & $-4.497^{*}$ & $-4.509^{*}$ \\
dgdp & -1.412 & -3.928 & -1.379 & -2.399 & $-4.263^{*}$ & $-4.181^{* *}$ & $-5.448^{*}$ & $-5.578^{*}$ \\
dtrop & -2.756 & -0.500 & -1.409 & -0.029 & $-4.209^{*}$ & $-4.961^{*}$ & $-4.158^{*}$ & $-4.863^{*}$ \\
dfdi & -3.102 & -5.465 & -2.854 & -5.466 & $-7.425^{*}$ & $-7.342^{*}$ & $-20.24^{*}$ & $-20.92^{*}$ \\
\hline
\end{tabular}

*Significant at $1 \% ; * *$ Significant at $5 \%$

To ensure that the model estimates are not spurious, we applied traditional methods of estimating unit root such as the Augmented Dickey-Fuller test (ADF, 1979) and the Philip-Perron (PP, 1990) test. Taking the first difference is enough to convert a nonstationary series into stationary. For Table 4, the null hypothesis of the ADF and PP tests is unit root at level $1 \%$ and $5 \%$. This test is to verify the stationary of variables. Possible asymmetric effects of government development expenditure on gross domestic product was analysed using the NARDL technique which decomposed the GOV rate series into two parts: (1) partial sum of positive change in GOV rate denoted by $\mathrm{GOV}^{+}$, and (2) partial sum of negative rate denoted by $\mathrm{GOV}^{-}$. When both of GOVs were included as separate regressors in the model, the following model was developed:

$$
\begin{aligned}
\mathrm{GDP}_{\mathrm{t}}= & \mathrm{C}+\alpha_{\mathrm{a}} \mathrm{GDP}_{\mathrm{t}-1}+\alpha_{1} \mathrm{GOV}_{\mathrm{t}-1}{ }^{+}+\alpha_{2} \mathrm{GOV}_{\mathrm{t}-1}{ }^{-}+ \\
& +\alpha_{1} \mathrm{FDI}_{\mathrm{t}-1}^{+}+\alpha_{2} \mathrm{FDI}_{\mathrm{t}-1}{ }^{-}+\mathrm{U}_{\mathrm{t}}
\end{aligned}
$$

Equation 2 is the ARDL model proposed by Pesaran et al. [14], and the final model is asymmetric as shown below in the general form of the NARDL (Nonlinear Autoregressive Distributed Lag Model):

$$
\begin{gathered}
\Delta G D P_{t}=\alpha+\beta_{0} G D P_{t-1}+\beta_{a} G D P_{t-1}+\beta_{1} \theta^{+} G O V_{t}^{+}+ \\
+\beta_{2} \theta^{-} G O V_{t}^{-}+\sum_{j-1}^{p-1} \varphi_{j} \Delta G D P_{t-j}+ \\
\sum_{j=0}^{q}\left(\pi_{j}^{+} \Delta G O V_{t-j}^{+}+\left(\pi_{j}^{-} \Delta G O V_{t-j}^{-}\right)+e_{t} \text { for } j=1, \ldots q\right.
\end{gathered}
$$

Where $\theta^{+}=p \beta^{+}$and $\theta^{-}=p \beta^{-}$

$\rho$ and $q$ are lag orders, and both

$$
\alpha_{1}=-\frac{\beta_{1}}{\beta_{0}} \text { and } \alpha_{2}=-\frac{\beta_{2}}{\beta_{0}}
$$

are the aforementioned long-run impacts of increasing foreign direct investment and reducing foreign direct investment on remittances, respectively. For data with negative signs for foreign direct investment, the authors transformed them to positive values using the procedure proposed by Busse and Hefeker [4]. Foreign direct

\begin{tabular}{|c|c|c|c|c|}
\hline & \multicolumn{3}{|c|}{ Long-Run Estimation } & \multirow[b]{2}{*}{ Prob. } \\
\hline Variable & Coefficient & $\begin{array}{c}\text { Std } \\
\text { Error }\end{array}$ & t-stat & \\
\hline $\mathrm{c}$ & 0.29 & 0.15 & 2.02 & 0.05 \\
\hline dgdp & 0.28 & 0.11 & 2.61 & 0.01 \\
\hline dtrop & 0.03 & 0.02 & 1.91 & 0.06 \\
\hline \multirow[t]{2}{*}{ dfdi } & -0.09 & 0.08 & -1.14 & 0.26 \\
\hline & \multicolumn{3}{|c|}{ Short-Run Estimation } & \\
\hline $\mathrm{c}$ & 0.29 & 0.15 & 2.02 & 0.05 \\
\hline dgdp & 0.94 & 0.18 & 5.28 & 0.00 \\
\hline dtrop & 0.09 & 0.05 & 1.99 & 0.05 \\
\hline dfdi & -0.29 & 0.25 & -1.19 & 0.24 \\
\hline $\operatorname{ect}(-1)$ & 0.39 & 0.14 & 2.79 & 0.00 \\
\hline AIC (lag) & $-17.851(2)$ & & & \\
\hline F-stat & 248.650 & & & \\
\hline Prob > F & 0.000 & & & \\
\hline R-squared & 0.971 & & & \\
\hline Root MSE & 0.017 & & & \\
\hline
\end{tabular}
investments are the most ideal form of capital inflows to emerging and developing countries because they are less susceptible to crises and sudden stops, as mentioned by Busse and Hefeker, [4].
Table 5. ARDL Long-Run and Short-Run Estimation Results $(2,0,0,0)$

*Significant at $1 \%$

In the first step, the authors employed the ARDL analysis to capture the long-run and short-run estimations for the model. The table above shows the results with the selected optimal maximum lag order by the Akaike Information Criteria (AIC). The short-run estimations were obtained from the ECM equation using the AIC with estimation error correction model and long-run estimations. Table 5 shows that all variables are significant in the long-run and short-run, excluding the foreign direct investment with the negative sign. The value of ECT (-1) is positive and significant at level 1\%, indicating that at least one direction exists, therefore proving a causal relationship.

$$
\begin{aligned}
\Delta \operatorname{InGEXP}_{t} & =\mu+\sum_{i=1}^{p} \gamma_{i} \Delta \operatorname{InGDP}_{t-i}+\sum_{j=1}^{p} \gamma_{j} \Delta \operatorname{InTRO}_{j-i}+ \\
& +\sum_{k=1}^{p} \gamma_{k} \Delta \operatorname{InFDI}_{k-i}+\text { vecm }_{t-1}+\mu_{t}
\end{aligned}
$$


The estimated gross domestic product has a high significance of $1 \%$ in both the short-run and long-run relationships. However, in two periods of time, foreign direct investment was found to be negative and not significant. Frimpong and Oteng [10] reported in a study in Ghana that FDI inflows have failed to generate the necessary linkages to the wider economy that are needed for the anticipated economic growth. Unlike ARDL, the formulation of NARDL allows for potential asymmetric effects of positive and negative changes in explanatory variables on the dependent variable.

Table 6. Asymmetric Estimation of Government Expenditure-Foreign Direct Investment

\begin{tabular}{|c|c|c|c|c|}
\hline Variable & Coefficient & Std Error & t-stat & Prob. \\
\hline $\operatorname{dexp}_{t-1}$ & -0.181 & 0.072 & -2.52 & 0.016 \\
\hline$d f d i_{t-1}^{+}$ & 0.189 & 0.129 & 1.47 & 0.150 \\
\hline$d f d i_{t-1}^{+}$ & 0.163 & 0.139 & 1.16 & 0.252 \\
\hline$\Delta d \exp _{t-1}$ & 0.259 & 0.141 & 1.85 & 0.072 \\
\hline$\Delta f d i_{t}^{+}$ & 0.672 & 0.227 & 2.96 & 0.006 \\
\hline$\Delta f d i_{t-2}^{+}$ & -0.045 & 0.083 & -0.55 & 0.587 \\
\hline$\Delta f d i_{t}^{-}$ & -0.131 & 0.086 & -1.52 & 0.138 \\
\hline$\Delta f d i_{t-1}^{-}$ & 0.482 & 0.257 & 1.88 & 0.068 \\
\hline \multirow[t]{2}{*}{ Const } & 0.241 & 0.093 & 2.60 & 0.013 \\
\hline & & F-stat & $\mathrm{P}>\mathrm{F}$ & \\
\hline$L_{f d i^{+}}$ & 1.049 & 4.399 & 0.043 & \\
\hline$L_{f d i^{-}}$ & -0.902 & 2.039 & 0.162 & \\
\hline & & & P-value & \\
\hline \multicolumn{3}{|c|}{ Portmanteau test } & 0.3492 & \\
\hline \multicolumn{3}{|c|}{ Breusch/Pagan heteroskedasticity } & 0.8068 & \\
\hline \multicolumn{3}{|c|}{ Ramsey Reset test (F) } & 0.9001 & \\
\hline \multicolumn{3}{|c|}{ Jarque-Bera test on normality } & 0.5480 & \\
\hline \multicolumn{3}{|c|}{ F-statistic } & & \\
\hline
\end{tabular}

Referring to Shin [20], the authors employed the NARDL to identify the relationship between development expenditure and foreign direct investment inflow. The techniques used were the interaction of both positive and negative shocks, as well as the interaction between the explanatory variable and the dependent variables in the long-run equilibrium. The results of the analysis are shown in the table below, with $\mathrm{L}^{\text {fdi+ }}$ and $\mathrm{L}^{\text {fdi- }}$ denoting the coefficient for foreign direct investment with asymmetric estimations in the positive and negative. Table 6 shows that the NARDL captures the asymmetries in the responses of government expenditure towards changes in foreign direct investment inflow. The long-run and short-run relationships were tested using the F-test as the significance is at 0.05 . The test indicated that the results are asymmetric for the long-run. The results show that when government expenditure increases by $1 \%$, foreign direct investment inflow increases by $1.05 \%$.


Figure 1. CUSUM and CUSUM of Squares

However, when government expenditure decreases, foreign direct investment also decreases by $0.9 \%$. This study performed four types of diagnostic tests. From the table, all model diagnostics have been found to be insignificant, thus it can be concluded that there is no autocorrelation, heteroscedasticity, misspecification, and non-normality. The next step is to test the structural stability of the model. We employed the CUSUM and CUSUM squares. From the results, the CUSUM and CUSUM squares indicated that the confidence level is within $5 \%$. The authors can therefore conclude that the model has no structural instability in its residuals.

\section{Concluding Remarks}

The current study aims at determining how Malaysia's fiscal policy measures interact with foreign direct investment. Malaysia is listed as one of the most conducive countries for foreign investments with the implementation of an investor-friendly environment. The major contributors to foreign direct investment in Malaysia for the period of 2017 to 2019 are the equity sector as well as investment in the stock market [17]. The 
authors used the empirical approach to test the short-run and long-run nonlinearities simultaneously through positive and negative partial sum decompositions of the explanatory variable. The test indicated that FDI is significant with positive interaction on fiscal accumulation for development expenditure. It is interesting to note that for both the analysis models, the autoregressive distributed lag and asymmetric model showed similar effects. These factors may explain why FDI inflow is affected when the government decreases its volume of allocation on development expenditure. As foreign investors have the opportunity to invest in other countries, the Malaysian government should thus consider allocating an amount of development expenditure in its annual budgets. There are several opportunities for Malaysia to lead as a hub of foreign investments, especially during this pandemic-caused economic crisis. Promotion by the Malaysian Investment Development Authority (MIDA), stable economic performance, pursuance of government projects with high impact especially mega projects, and tax benefits are some of the attractions needed for FDI inflow.

As a recommendation, the share of GDP for development expenditure should be increased to $5 \%$ of the annual GDP as a show of confidence and to attract investors. As shown in Table 1, the share of GDP for development expenditure is less than $5 \%$. The findings have proven the significant impact of development expenditure towards economic growth in the long-run. The smaller amount of GDP allocated to development expenditure compared to the operating expenditure of more than $15 \%$ of the GDP should be reconsidered in order to attract new investors.

\section{REFERENCES}

[1] Ak, M. Z., Kirca, M., and Altintaş, N. The impacts of financial development on growth: A time-varying causality analysis for Turkey. Zbornik Radova Ekonomskog Fakulteta u Rijeci: Časopis Za Ekonomsku Teoriju i Praksu/Proceedings of Rijeka Faculty of Economics: Journal of Economics and Business, 34(2), 529-554, 2016. DOI: https://doi.org/10.18045/zbefri.2016.2.529

[2] Ahad, M., and Dar, A. A."Modelling the asymmetric impact of defense spending on economic growth: An evidence from non-linear ARDL and multipliers", Journal of Economic and Administrative Sciences, Vol. 33 Issue: 2, pp.131-149, 2017.

[3] Barro, R., J. Government spending in a simple model of endogenous growth. Journal of Political Economy 98(S5): 103-125, 1990.

[4] Busse, M., \& Hefeker, C. Political risk, institutions and foreign direct investment. European Journal of Political Economy, 23(2), 397-415, 2007, DOI: https://doi.org/10.1 016/j.ejpoleco.2006.02.003
[5] Charles P. Oman. Policy Competition for Foreign Direct Investment A Study of Competition among Governments to Attract FDI. Retrievedhttps://www.oecd.org/investment/m ne/2089936.pdf, 1999.

[6] Chen, Z., Lv, B., \& Liu, Y. Financial development and the composition of government expenditure: Theory and cross-country evidence. International Review of Economics \& Finance, 64, 600-611 ,2019. DOI: https://doi.org/10.101 6/j.iref.2019.09.006

[7] Dreher, A., Sturm, J.-E., \& Ursprung, H. W. The impact of globalization on the composition of government expenditures: Evidence from panel data. Public Choice, 134(3-4), 263-292, 2007, DOI: https://doi.org/10.1007/s1 1127-007-9223-4.

[8] Easterly, W. and Rebelo, S. 'Fiscal policy and economic growth', Journal of monetary economics 32(3), 417-458, 1993.

[9] Feyzioglu, T., Swaroop, V., and Zhu, M. A Panel Data Analysis of the Fungibility of Foreign Aid. The World Bank Economic Review, 12(1), 29-58, 1998, DOI: https://doi.org/10.1093/wber/12.1.29

[10] Frimpong, J. M., and Oteng-Abayie, E. F. "Bivariate Causality Analysis between FDI Inflows and Economic Growth in Ghana". Proceedings, 3rd African Finance Journal Conference, "Research in Development Finance for Africa", 12th - 13th July, 2006, Ghana.

[11] Gunby, P., Jin, Y., and Robert Reed, W. Did FDI Really Cause Chinese Economic Growth? A Meta-Analysis. World Development, 90, 242-255, 2017, DOI: https://doi.org/10.1016/j.worlddev.2016.10.001

[12] Granger, C.W.J. and Yoon, G. Hidden Cointegration. Department of Economics Discussion Paper 2002-02, University of California, 2002. San Diego.

[13] Pesaran, M.H. and Shin, Y. "An Autoregressive Distributed Lag Modelling Approach to Cointegration Analysis." Econometrics and Economic Theory in the 20th Century: The Ragnar Frisch Centennial Symposium, Strom, S. (ed.) Cambridge University Press. 1999.

[14] Pesaran, M. H., Y. Shin, and R. Smith. Bounds testing approaches to the analysis of level relationships. Journal of Applied Econometrics, 16, pp. 289-326, 2001.

[15] Katiman, R., Abdul Rahim, M. Nor., Er. A. Choy., Aishah@Eshah, M., Zaini S.,Hasan M. N., and Rosniza, A. Impak pembangunan Bandar Baru Nusajaya Wilayah Iskandar Malaysia terhadap kesejahteraan hidup penduduk asal setempat. GEOGRAFIA Online. Malaysian Journal of Society and Space. Vol 7. 14 - 28, 2011.

[16] Lim, T. G., Shivee, R. and Woon, L.L. Crazy Rich Asian Countries? The Impact of FDI Inflows on the Economic Growth of the Economies of Asian Countries: Evidence from An NARDL Approach. International Journal of Economics and Management. Vol 1 (1). 43-67, 2020.

[17] Malaysia (2020a) Evolution FDI in Malaysia. Department of Statistic Malaysia. Retrieved fromhttps://www.dosm.go v.my/v1/uploads/files/6_Newsletter/Newsletter\%202020/D OSM_BPIP_3.2020_Siri-64.pdf

[18] Munir, K., \& Ameer, A. Nonlinear effect of FDI, economic 
growth, and industrialization on environmental quality. Management of Environmental Quality: An International Journal, 31(1), 223-234, 2020. DOI: https://doi.org/10.110 8/meq-10-2018-0186

[19] Malaysia (2021b) Federal Government Expenditure. Fiscal Outlook. Minitstry of Treasury http://www1.treasury.gov. $\mathrm{my} / \mathrm{pdf} /$ revenue/2021/section3.pdf

[20] Shin, Y. Modelling Asymmetric Cointegration and Dynamic Multipliers in a Nonlinear ARDL Framework. Festschrift in Honor of Peter Schmidt. 2014.

[21] Taasim, S., I. and Yusoff, R. Telecommunications Infrastructure Consequence to Economic Growth in Malaysia: Time Series Analysis. International Journal of
Computer Trends and Technology. Volume 18 (5): 175179, 2014.

[22] Tang, L., Sun, S., and Yang, W. Does government education expenditure boost intergenerational mobility? Evidence from China. International Review of Economics \& Finance, 74, 13-22,2021. DOI: https://doi.org/10.1016/j. iref.2021.02.001

[23] Waqih, M. A. U., Bhutto, N. A., Ghumro, N. H., Kumar, S., and Salam, M. A. Rising environmental degradation and impact of foreign direct investment: An empirical evidence from SAARC region. Journal of Environmental Management, 243, 472-480, 2019. DOI: https://doi.org/10.1016/j.jenvman.2019.05.001 